\title{
Allelopathic effect of Prymnesium parvum on a natural plankton community
}

\author{
Giovana O. Fistarol*, Catherine Legrand, Edna Granéli
}

Department of Biology and Environmental Science, University of Kalmar, Barlastgatan 1, 39182 Kalmar, Sweden

\begin{abstract}
The allelopathic effect of Prymnesium parvum (Prymnesiophyta), which produces toxins with haemolytic, ichthyotoxic and cytotoxic properties, was investigated on a natural plankton community. Under controlled conditions, 3 laboratory bioassays were performed by adding cell-free filtrate from a $P$. parvum culture into different size fractions $(<150,<100$ and 20 to $150 \mu \mathrm{m})$ of a natural Baltic Sea plankton community. The effect of $P$. parvum cell-free filtrate was determined by measuring chlorophyll $a$, cell numbers (phytoplankton, ciliates, bacteria), carbon $\left({ }^{14} \mathrm{C}\right)$ uptake by phytoplankton and the incorporation of ${ }^{3} \mathrm{H}$-leucine by bacteria. P. parvum cell-free filtrate affected the whole phytoplankton community, resulting in a decrease in both chlorophyll $a$ and carbon uptake. Furthermore, the plankton groups present in the community exhibited different sensitivity to the cellfree filtrate. While growth of cyanobacteria and dinoflagellates was inhibited, that of diatoms and ciliates was not only completely suppressed, but no cells were present at the end of the experiment in the bottles with P. parvum filtrate. In all experiments, therefore, cyanobacteria and dinoflagellates were the most resistant groups, which led to their dominance in the treatments with filtrate compared to controls. Bacterial production was also negatively affected by $P$. parvum filtrate. The results show that compounds released by $P$. parvum induce changes in the plankton community structure, killing other members of the marine food-web, especially other phytoplankton (allelopathy), and suggest that secreted compounds of $P$. parvum are inhibitory to potential grazers (ciliates). It is proposed that allelopathy is an important process in the ecology of $P$. parvum.
\end{abstract}

KEY WORDS: Prymnesium parvum - Allelopathy · Natural plankton community · Phytoplankton · Ciliates $\cdot$ Bacteria

Resale or republication not permitted without written consent of the publisher

\section{INTRODUCTION}

Prymnesium parvum is a regular component of the coastal plankton community in many parts of the world. Prymnesium species may also form harmful blooms in almost any low-salinity, nutrient-rich, temperate waters in both the northern and southern hemispheres. Therefore, P. parvum is potentially one of the most harmful microalgae, causing severe damage to coastal marine ecosystems and fish farming (Igarashi et al. 1996, Edvardsen \& Paasche 1998). In the Baltic Sea, $P$. parvum is part of the regular phytoplankton community (Edler et al. 1984, Lindholm 1998), and blooms with deleterious effects have also been reported for these waters (Holmquist \& Willén 1993, Larsen et al. 1993, Johnsen et al. 1997, Lindholm 1998).
Shilo (1981) demonstrated that the toxic compounds produced by Prymnesium parvum are actively released into the water, i.e. the toxicity of this species is not restricted to toxin released at death and lysis of cells. The toxins produced by $P$. parvum display haemolytic, ichthyotoxic and cytotoxic effects (Shilo 1981, Igarashi et al. 1998). Two compounds responsible for these effects have been hitherto isolated: the toxins prymnesin-1 (PRM1) and prymnesin-2 (PRM2) (Igarashi et al. 1995). The harmful effects of these toxins seem to be due to their ability to increase cell membrane permeability and disturbance of the cellular ion balance. This general effect on the membrane may, therefore, affect organisms ranging from protozoans to fishes (Edvardsen \& Paasche 1998). It has also been demonstrated that compounds released by $P$. parvum 
have allelopathic effects on the diatom Thalassiosira weissflogii, the dinoflagellate Prorocentrum minimum and the cryptomonad Rhodomonas cf. baltica, but not on other strains of Prymnesium, e.g. P. parvum cf. patelliferum, which is also known to produce prymnesins (Johansson 2000).

The ability of phytoplankton species to form blooms is, among other factors, related to their competitive capacity for resources. Competition between phytoplankton species can occur by exploitation, whereby direct use of a resource reduces its availability to the competitor, or by interference, when access to a resource is denied to competitors by the dominant species (Valiela 1995). Between phytoplankton species, the release of allelopathic compounds can be one form of interference competition by which the species producing allelopathic compounds prevents the growth of the competitor, thus achieving dominance. Selective promotion or inhibition of the growth of individual species by such metabolites would presumably influence competition and succession in aquatic environments. If the toxins released by Prymnesium parvum have inhibitory effects on the growth of other phytoplankton species, this would result in a competitive advantage and contribute to the success of this species in forming a bloom.

Allelopathy has been demonstrated among phytoplankton in cultures, but very few studies have dealt with its possible effect on natural phytoplankton communities (Legrand et al. in press). The aim of our study was to investigate the effect of cell-free filtrate of Prymnesium parvum on a natural plankton community in enclosure experiments. The study involved evaluating the response of different size fractions of the plankton community and the different susceptibility of the plankton groups to $P$. parvum allelopathic compounds, as determined by specific composition, biomass and production.

\section{MATERIALS AND METHODS}

Sampling of natural plankton community. Prymnesium parvum is found all year around in the Baltic Sea, but bloom events occur during summer, usually at the end of June and July (Lindholm 1998). Therefore, the natural plankton community used in our experiment was collected on 13 June 2000, and represented the community preceding P. parvum blooms, i.e. the community that it must outcompete to achieve dominance. Water containing the indigenous plankton community was sampled from the open Baltic Sea $\left(56^{\circ} 55.85^{\prime} \mathrm{N}, 17^{\circ} 01.82^{\prime} \mathrm{E}\right)$ at $5 \mathrm{~m}$ depth with a submersible pump. During sampling, the water temperature was $10.5^{\circ} \mathrm{C}$ and salinity $7.1 \%$. The water was filtered through a $150 \mu \mathrm{m}$-mesh nylon net to remove the mesozooplankton.

Prymnesium parvum culture. $P$. parvum Strain KAC 39 (Kalmar Algal Collection, Department of Biology and Environmental Science, University of Kalmar) was grown in modified $f / 10$ medium (Guillard 1975) (nitrate $=116 \mu \mathrm{M}$, phosphate $=7.2 \mu \mathrm{M}$, selenium $=$ $0.01 \mu \mathrm{M}, \mathrm{pH}=7.9$ to 8.4 ), in a $10 \mathrm{l}$ glass bottle containing $6 \mathrm{l}$ of culture, at $11^{\circ} \mathrm{C}, 80 \mu \mathrm{mol}$ photons $\mathrm{m}^{-2} \mathrm{~s}^{-1}$ and a light:dark cycle of 19:5 h. The culture medium comprised filtered Baltic Sea water (GF/C glass microfibre filters) with a salinity of $7.1 \%$. The biomass of $P$. parvum culture was monitored by cell counting and measuring chlorophyll a concentrations. During the exponential phase, when the $P$. parvum culture reached a concentration of $4.5 \times 10^{5}$ cells ml$^{-1}$, the culture was diluted every second day by removing $20 \%$ of the volume and replacing it with a corresponding volume of fresh medium to maintain the P. parvum culture in a steady state. The removed volume of culture was used to test the allelopathic effect of $P$. parvum on the plankton community (Fig. 1). On 2 occasions-at the start of the dilution period and after $6 \mathrm{~d}$ of dilutionnitrate $\left(\mathrm{N}-\mathrm{NO}_{3}{ }^{-}\right)$, ammonia $\left(\mathrm{N}-\mathrm{NH}_{4}{ }^{+}\right)$and phosphate $\left(\mathrm{P}_{-} \mathrm{PO}_{4}{ }^{3-}\right)$ concentrations were measured in the P. parvum culture.

The haemolytic activity of Prymnesium parvum was measured in the cell-free filtrate to determine its toxicity. Cell-free filtrate from $P$. parvum culture was obtained on one of the sampling occasions by gentle filtration through GF/F glass microfibre filters. Part of the cell-free filtrate obtained was immediately used in an haemolytic assay (haemolytic activity at Time 0 ); the remainder was kept under the same culture conditions as the allelopathic bioassay for $48 \mathrm{~h}$ (time between filtrate additions) and was then used in another haemolytic test to determine if toxicity had altered during this $48 \mathrm{~h}$ period. We could thus assess if toxicity was lost or reduced between filtrate additions.

Experimental set-up. The effect of Prymnesium parvum was tested on a natural plankton community $(<150 \mu \mathrm{m}$, Expt 1). The first results of this experiment (Day 2) indicated a strong allelopathic effect of $P$. parvum, and some differences in the sensitivity of the phytoplankton groups to $P$. parvum filtrate. Therefore, 2 additional experiments were performed to investigate in detail the effect of $P$. parvum on different groups of the plankton community. Since the first results indicated that the larger organisms (filamentous cyanobacteria and dinoflagellates) were more resistant and small nanoflagellates and diatoms more sensitive, the natural plankton community was fractionated into 2 parts to remove large cyanobacterial filaments $(<100 \mu \mathrm{m}$, Expt 2), and nanoflagellates (20 to $150 \mu \mathrm{m}$, Expt 3) (Fig. 1). 
To test the allelopathic effect of Prymnesium parvum on the plankton communities, freshly prepared $P$. parvum cell-free filtrates (allelopathy is only considered to occur if the affecting compounds are released to the medium) were added to triplicate bottles containing the natural plankton community ( 3 bottles for each size fraction: Expts 1 to 3). Filtrates were obtained by gentle filtration of the $P$. parvum culture through GF/F glass microfibre filters. Filtrates were examined microscopically for the presence of $P$. parvum cells, but no cells were observed in the filtrate. Controls (also in triplicate) were made by adding modified $f / 10$ medium, with concentrations of nitrate and phosphate adjusted to the same concentrations as in the $P$. parvum filtrate in order to maintain the same nutrient levels in both controls and filtrate treatments.

The natural plankton communities (Expt 1) and the different size fractions (Expts 2 and 3) were diluted by removing $30 \%$ of the volume $(300 \mathrm{ml}$ in Expt 1, and $90 \mathrm{ml}$ in Expts 2 and 3) and replacing with a corresponding volume of Prymnesium parvum filtrate or control medium. Dilutions were made every second day at the start of the dark period. The bottles were incubated at $11^{\circ} \mathrm{C}$ with a light:dark cycle of 19:5 h, under environmental conditions similar to those at the time of sampling.

The 3 experiments using different size fractions of the natural plankton community were set up as described above (Fig. 1). Volumes, duration, and measured parameters were as follows: Expt 1 used 2 l glass bottles containing $1 \mathrm{l}$ of the plankton community $(<150 \mu \mathrm{m})$, and was run for $8 \mathrm{~d}$. Measurements of carbon $\left({ }^{14} \mathrm{C}\right)$ uptake, bacterial production and abundance, and cell enumeration of the different plankton taxa were made every second day. Chlorophyll a concentrations were analysed daily to follow the growth of the phytoplankton community.

Expts 2 and 3 used 0.51 Erlenmeyer glass flasks containing $300 \mathrm{ml}$ of the plankton community with organisms of $<100 \mu \mathrm{m}$ and 20 to $150 \mu \mathrm{m}$ respectively, and were run for $6 \mathrm{~d}$. Cell enumeration of the different plankton taxa took place on the first and the last day of the experiments, while chlorophyll a concentrations were measured daily.

The allelopathic activity of Prymnesium parvum towards the different size fractions of the phytoplankton community was assessed as an allelopathic effect
(AE). This was calculated as the difference between the cell concentration in the controls(Ctn) on a specific day and that in the filtrate treatments(Ftn) (on the same day normalized by the cell concentration in the controls and expressed as a percentage (Eq. 1) representing the number of cells that died in the filtrate treatment compared to the controls:

$$
x=\left[\frac{(\mathrm{Ctn}-\mathrm{Ftn})}{\mathrm{Ctn}}\right] \times 100
$$

Thus, comparison of the cell concentration in the control on the last day of an experiment with the cell concentration in the filtrate treatment on the same day would reveal any interaction (e.g. competition) that might have occurred in the experiment bottles; i.e. the 'allelopathic effect', being the difference between the

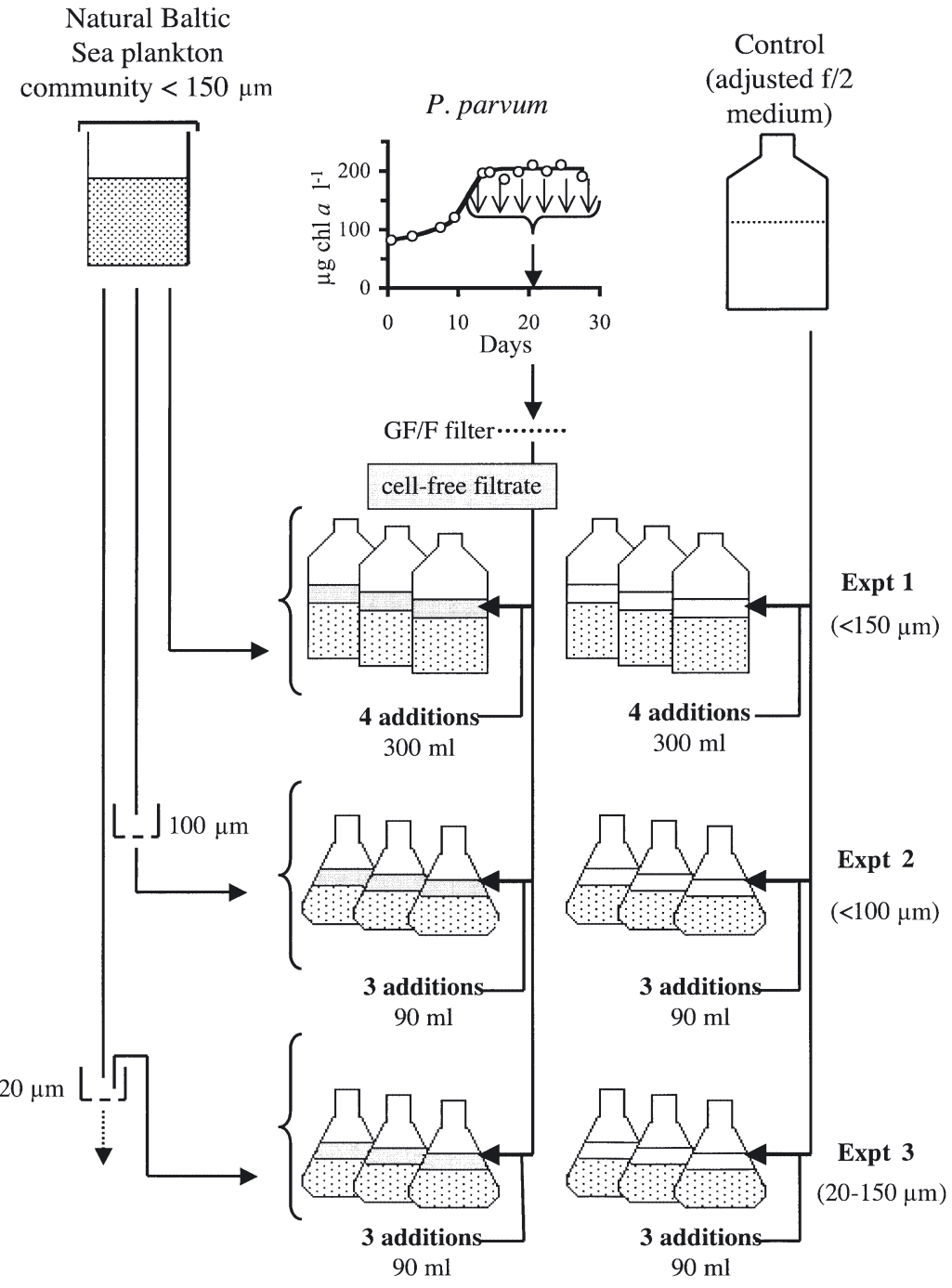

Fig. 1. Schematic representation of experimental set-up used to test allelopathic effect of Prymnesium parvum cell-free filtrates on natural plankton community. Growth curve of $P$. parvum is also shown 
2 treatments due to allelopathic compounds. The group abundances in the control flasks represent normal interactions between the phytoplankton community in the experiment, while those in the experimental flasks represent interactions resulting from the presence of allelopathic compounds.

Analytical procedures. Samples were preserved with Lugol's solution for enumeration of Prymnesium parvum and other plankton organisms. The samples were settled and counted with an inverted microscope using the method described by Utermöhl (1958). At least 20 cells of a specific taxon and 300 cells in total were counted per sample to estimate the abundance of phytoplankton and ciliates.

Chlorophyll a concentrations were determined using ethanol extracts of GF/F filters (Jespersen \& Christoffersen 1987). Nitrate, ammonia and phosphate were analyzed according to Valderama (1995).

Each haemolytic assay ( $0 \mathrm{~h}$ after filtration and $48 \mathrm{~h}$ after the filtrate was obtained) was performed in duplicate. Horse blood was washed and resuspended in $40 \mathrm{ml}$ of isotonic phosphate buffer, IPB $\left(80 \mathrm{~g} \mathrm{l}^{-1} \mathrm{NaCl}\right.$, $2 \mathrm{~g} \mathrm{l}^{-1} \mathrm{KCl}, 6.06 \mathrm{~g} \mathrm{l}^{-1} \mathrm{NaH}_{2} \mathrm{PO}_{4}, 2 \mathrm{~g} \mathrm{l}^{-1} \mathrm{NaH}_{2} \mathrm{PO}_{4} \cdot \mathrm{H}_{2} \mathrm{O}$, $\mathrm{pH}$ 7.3). We added 12 aliquots of $50 \mu \mathrm{l}$ of Prymnesium parvum cell-free filtrate ranging from 4 to $100 \%$ (in IPB) to $200 \mu \mathrm{l}$ of horse blood cell suspension in a microplate well (Falcon, 96 wells). A standard curve was made with saponin. After incubation for $1 \mathrm{~h}$ at room temperature in the dark, the microplates were centrifuged (5 min, 3000 rpm; Beckman Allegra ${ }^{\mathrm{TM}}$ 21 centrifuge), and $115 \mu \mathrm{l}$ of the supernatant were transferred to a new microplate $\left(\right.$ Costar $^{\circledR}$, black, 96 wells). The absorbance at $540 \mathrm{~nm}$ was read on a microplate reader (Fluostar 403). The results were expressed as $H_{50}$ (amount of cells causing $50 \%$ haemolysis), calculated using the 'non-linear estimation' module of STATISTICA for Windows (StatSoft). The absorbance value obtained in the tests were fitted with a sigmoidal curve according to Eq. (2):

$$
A_{540}=A_{\max }-\frac{A_{\max }-A_{\min }}{1+\left(\frac{[C]}{H E_{50}}\right)^{h}}
$$

where $A_{540}$ is the absorbance of the samples, $A_{\max }$ is the theoretical maximal absorbance when all the red blood cells have lysed, $A_{\min }$ is the minimum absorbance when no red blood cells have lysed, $C$ is the corresponding cell concentration (cell $\mathrm{l}^{-1}$ ) of the filtrate dilutions in the test solution, $h$ is the shape factor and $H E_{50}$ is the concentration of cells when $50 \%$ of the blood cells have lysed (Stolte et al. 2002).

Carbon uptake was measured as ${ }^{14} \mathrm{C}$-uptake by the phytoplankton according to the method of ErtebjergNielsen \& Bresta (1984). Radioactive $\mathrm{NaH}^{14} \mathrm{CO}_{3}(2 \mu \mathrm{Ci})$ was added to $25 \mathrm{ml}$ glass flasks. For each sample,
1 light and 1 dark bottle were incubated in the same room conditions as the experiments. Bacterial production was measured as bacterial uptake of ${ }^{3} \mathrm{H}$-leucine (specific activity $150 \mathrm{Ci} \mathrm{mmol}{ }^{-1}$ ) according to the method of Smith \& Azam (1992). The final leucine concentration was $20 \mathrm{nmol}^{-1}$ and the incubations were run for $1 \mathrm{~h}$ under the same in vitro conditions as the experiments. Bacterial protein production was converted to bacterial production ( $\mu \mathrm{g} \mathrm{C}$ bacterium ${ }^{-1} \mathrm{l}^{-1} \mathrm{~h}^{-1}$ ) using the conversion factor of 0.86 (Simon \& Azam 1989). Bacterial abundance was estimated by flow cytometry (FACSCalibur, Becton Dickinson) according to del Giorgio et al. (1996).

Statistical analyses. The statistical analyses were performed using the software STATISTICA version 4.1 for Windows. A Student's $t$-test was used to compare differences in biomass between the control and the treatment with Prymnesium parvum filtrate for each day of the allelopathic experiments, and for the haemolytic assay.

\section{RESULTS}

\section{Prymnesium parvum growth and toxicity}

The biomass of the Prymnesium parvum culture used as the source of the cell-free filtrate for the allelopathic bioassays was kept at $198.5 \pm 8.4 \mu \mathrm{g}$ chlorophyll $\mathrm{a} \mathrm{l}^{-1}$ and $460 \times 10^{3} \pm 27$ cells $\mathrm{ml}^{-1}$ during the experiment (Fig. 1).

The nutrient concentrations in the Prymnesium parvum filtrate on the first day of dilution were $\mathrm{N}-\mathrm{NO}_{3}{ }^{-}=$ $47.4 \mu \mathrm{M}$ and $\mathrm{P}_{-} \mathrm{PO}_{4}{ }^{3-}=5.6 \mu \mathrm{M}$, and after $6 \mathrm{~d}$, they were still at similar levels $\left(\mathrm{N}-\mathrm{NO}_{3}{ }^{-}=45.6 \mu \mathrm{M}\right.$ and $\mathrm{P}-\mathrm{PO}_{4}{ }^{3-}=$ $4.6 \mu \mathrm{M})$. Ammonia concentrations were below analytical detection $(0.1 \mu \mathrm{M})$ on both occasions. Nutrient concentrations in the seawater-based medium added to the controls were adjusted to the nutrient concentrations in the $P$. parvum filtrate.

The haemolytic activity in the cell-free filtrate of Prymnesium parvum at Time $0 \mathrm{~h}$ corresponded to an $H E_{50}$ of $3.5 \times 10^{8}$ cell $\mathrm{l}^{-1}$. After $48 \mathrm{~h}$, no haemolytic activity was detected in the filtrate (no haemolysis was observed in the filtrate addition of $4.5 \times 10^{8} \mathrm{cell}^{-1}$, i.e. $100 \%=$ no dilution).

\section{Composition of different fractions of plankton community}

The plankton community in Expt $1(<150 \mu \mathrm{m})$ was composed of different species of dinoflagellates, nanoflagellates, cyanobacteria, chrysophyceans, diatoms and ciliates (Table 1). In Expt $2(<100 \mu \mathrm{m})$, the same 
plankton groups were present as in Expt 1, although the filtration through $100 \mu \mathrm{m}$-mesh removed $97 \%$ of the filamentous cyanobacteria. In Expt 3, nanoflagellates and small ciliates were removed from the 20 to $150 \mu \mathrm{m}$ fraction. Large ciliates $(>20 \mu \mathrm{m})$, initially present in the plankton community, were also excluded by the filtration process. Thus, only dinoflagellates, filamentous cyanobacteria and diatoms were present in Expt 3.

\section{Effect of Prymnesium parvum cell-free filtrates on different plankton size fractions}

Chlorophyll $a$ and carbon uptake

In all 3 experiments, chlorophyll a concentrations decreased in the treatments with Prymnesium parvum cellfree filtrate while they increased in the controls (Fig. 2). Chlorophyll a concentrations decreased significantly with additions $P$. parvum cell-free filtrate (Student's $t$-test, $\mathrm{p}<0.01$ ) after $2 \mathrm{~d}$ (corresponding to 1 addition of filtrate) in Expts 1 and 2, and after $3 \mathrm{~d}$ (corresponding to 2 additions of filtrate) in Expt 3. Consequently, the growth rates of the different plankton fractions were negative in the treatments with filtrate and positive in the controls, a significant difference at $\mathrm{p}<0.01$ (Student's $t$-test; Table 2). Carbon uptake, measured from phytoplankton community
Table 1. Cell concentrations (cells $\times 10^{2} \mathrm{l}^{-1}$ ) of plankton species/groups in natural Baltic Sea community at beginning (Day 1$)$ and end (Day 8$)$ of Expt $1(<150 \mu \mathrm{m})$ in treatments with added Prymnesium parvum cell-free filtrate and in controls. Last column shows allelopathic effect, $\mathrm{AE}(\mathrm{n}=3$, mean $\pm \mathrm{SD})$, calculated as difference between cell concentration in controls and that in filtrate treatments normalized by cell concentration in controls

\begin{tabular}{|c|c|c|c|c|}
\hline \multirow{3}{*}{$\begin{array}{l}\text { Species } \\
\text { Groups }\end{array}$} & \multicolumn{3}{|c|}{- Cell concentration -} & \multirow[t]{3}{*}{$\mathrm{AE}(\%)$} \\
\hline & \multirow[t]{2}{*}{ Day 1} & \multirow{2}{*}{\multicolumn{2}{|c|}{$\begin{array}{l}\text { Day } 8-\text { filtrate control } \\
\text { + }\end{array}$}} & \\
\hline & & & & \\
\hline \multicolumn{5}{|l|}{ Dinoflagellates } \\
\hline Dinophysis norvegica & 4.3 & 1.4 & 6.8 & $79 \pm 7.4$ \\
\hline D. acuminata & 5.3 & 0.3 & 0.7 & $56 \pm 23.1$ \\
\hline Amphidinium sp. & 2.4 & 0 & 248 & $100 \pm 0$ \\
\hline Gymnodinium simplex & 15.4 & 124 & 309 & $60 \pm 16.7$ \\
\hline Others $^{\mathrm{a}}$ & 30.9 & 0.2 & 24.7 & $99 \pm 1.5$ \\
\hline Total & 58.4 & 126 & 589 & $79 \pm 13.4$ \\
\hline \multicolumn{5}{|l|}{ Nanoflagellates } \\
\hline$<10 \mu \mathrm{m}$ & 1750 & 2330 & 102850 & $98 \pm 0.1$ \\
\hline \multicolumn{5}{|l|}{ Cyanobacteria } \\
\hline Pseudoanabaena spp. & 650 & 420 & 985 & $58 \pm 15.1$ \\
\hline Anabaena spp. & 17.0 & 77.5 & 197 & $61 \pm 4.6$ \\
\hline Aphanizomenon sp. & 361 & 0 & 0 & \\
\hline Nodularia spumigena & 7.2 & 0 & 0 & \\
\hline Total & 1035 & 497.5 & 1182 & $60 \pm 12.9$ \\
\hline \multicolumn{5}{|l|}{ Chrysophyceae } \\
\hline Dinobryon sp. & 4350 & 0 & 0 & \\
\hline \multicolumn{5}{|l|}{ Diatoms } \\
\hline Skeletonema costatum & 13.0 & 0 & 15420 & $100 \pm 0$ \\
\hline Fragilaria spp. & 1250 & 0 & 0 & \\
\hline Chaetoceros spp. & 500 & 0 & 2830 & $100 \pm 0$ \\
\hline Total & 513 & 0 & 18250 & $100 \pm 0$ \\
\hline \multicolumn{5}{|l|}{ Ciliates } \\
\hline$<20 \mu \mathrm{m}$ & 1.0 & 0 & 28 & $100 \pm 0$ \\
\hline $20-50 \mu \mathrm{m}$ & 1.2 & 0 & 55 & $100 \pm 0$ \\
\hline$>50 \mu \mathrm{m}$ & 17.6 & 0 & 9.5 & $100 \pm 0$ \\
\hline Total & 19.8 & 0 & 92.5 & $100 \pm 0$ \\
\hline \multicolumn{5}{|c|}{$\begin{array}{l}\text { a Others = dinoflagellates with low biomass that were combined: Katodinium } \\
\text { sp., Protoperidinium sp., Peridinium umbonatum, Gonyaulax sp., Hetero- } \\
\text { capsa triquetra }\end{array}$} \\
\hline
\end{tabular}

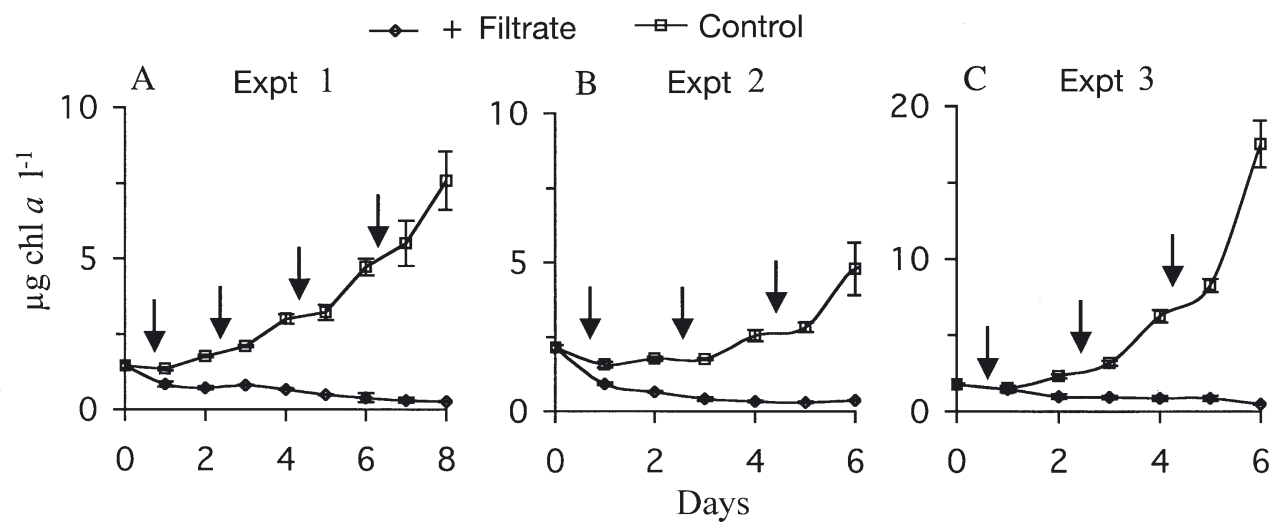

Fig. 2. Growth curve of phytoplankton communities (expressed as chlorophyll a) for Expts $1(<150 \mu m$ fraction of phytoplankton community), $2(<100 \mu \mathrm{m})$ and $3(20$ to $150 \mu \mathrm{m})(\mathrm{n}=3$, mean $\pm \mathrm{SD})$. Arrows indicate filtrate addition 


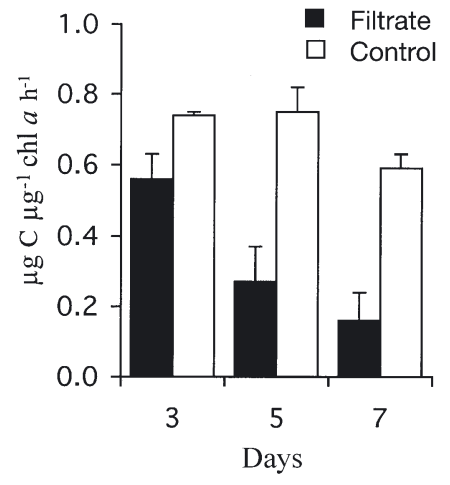

Fig. 3. Carbon $\left({ }^{14} \mathrm{C}\right)$ uptake during Expt 1 in controls and treatments with Prymnesium parvum cell-free filtrate. $\mathrm{n}=3$, mean $\pm \mathrm{SD}$

(<150 $\mu \mathrm{m}$ : Expt 1), normalized for chlorophyll a, was also significantly lower in the treatment with $P$. parvum filtrates than in the controls (Fig. 3).

Cell concentrations: allelopathic effect on different phytoplankton groups

The decrease in cell concentration and the allelopathic effect in Table 1 show the impact of Prymnesium parvum filtrate on the plankton species/groups in Expt 1.

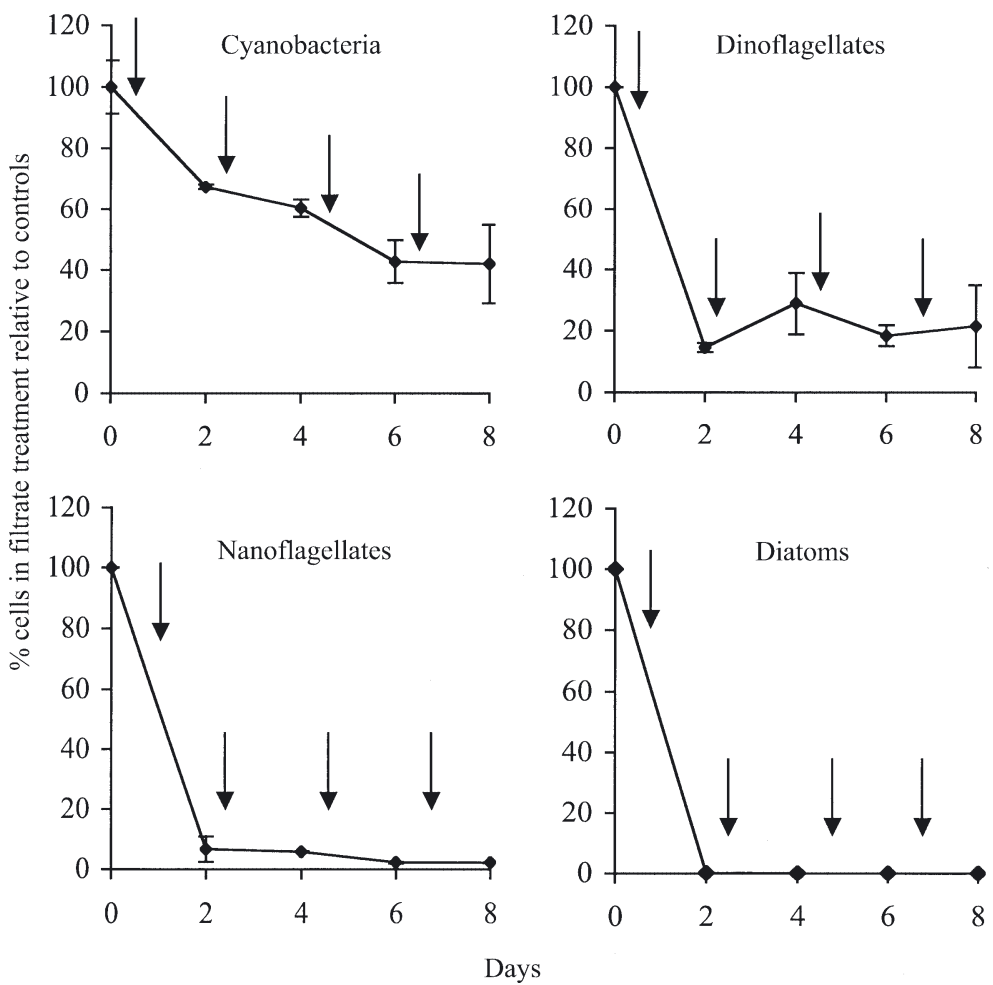

Fig. 4. Decrease in phytoplankton concentration for each group in Expt 1. $\mathrm{n}=3$, mean $\pm \mathrm{SD}$. Arrows indicate filtrate addition
Table 2. Growth rates of phytoplankton community (based on chlorophyll a concentration) in treatments with Prymnesium parvum cell-free filtrate and in controls for all 3 experiments $(\mathrm{n}=3$, mean $\pm \mathrm{SD})$

\begin{tabular}{|lcr|}
\hline \multirow{2}{*}{ Expt } & \multicolumn{2}{c|}{ Growth rate $\left(\mathrm{d}^{-1}\right)$} \\
& Filtrate & Control \\
\hline 1 & $-0.24 \pm 0.04$ & $0.25 \pm 0.03$ \\
2 & $-0.38 \pm 0.03$ & $0.27 \pm 0.02$ \\
3 & $-0.20 \pm 0.04$ & $0.48 \pm 0.02$ \\
\hline
\end{tabular}

A decrease in the phytoplankton concentration in the filtrate treatments compared to the controls was observed in all phytoplankton groups during Expt 1 (Fig. 4). Nanoflagellate and diatom abundance decreased sharply (>90\%) after the first filtrate addition compared to controls. Cyanobacteria and dinoflagellate abundance also decreased in treatments with Prymnesium parvum filtrate compared to controls (Fig. 4), and the growth of these 2 groups was poor compared to controls. After the first filtrate addition, approx. $80 \%$ of dinoflagellate cells disappeared; however, the remaining $20 \%$ (mainly Gymnodinium simplex) sustained a low growth until the end of the experiment (see also Table 1). Filamentous cyanobacteria abundance also decreased as a result of $P$. parvum filtrate addition. Only Anabaena spp. showed a low growth in the filtrate treatment, although this was much lower than in the controls.

The allelopathic effect of Prymnesium parvum at the end of the experiment differed between the 4 dominant phytoplankton groups in Expts 1, 2 and 3 (Fig. 5, Table 1). The highest allelopathic effect was on nanoflagellates (>95\%) and diatoms (100\%) in all experiments, while dinoflagellates and cyanobacteria were less affected. The allelopathic effect of $P$. parvum on the latter 2 groups varied between experiments (Fig. 5). In Expts 1 and 2, cyanobacteria comprised the most resistant group, with a lower allelopathic effect than the other groups, followed by dinoflagellates, while in Expt 3, dinoflagellates were more resistant than cyanobacteria.

The dinoflagellates were the only group in which the various species were differentially affected by Prymnesium parvum allelopathic compounds, with the allelopathic effect producing between 56 and 100\% inhibition (Table 1).

The cyanobacteria Aphanizomenon sp. and Nodularia spumigena, the chrysophyceaen 

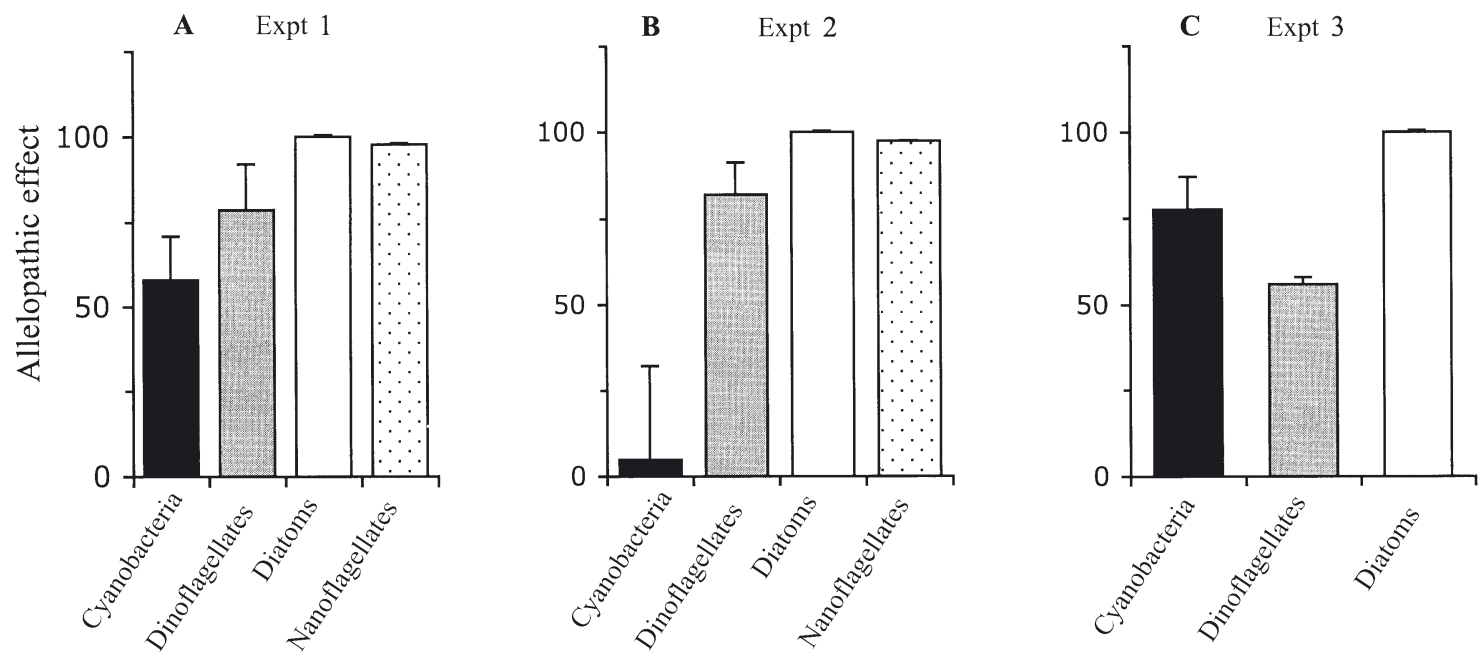

Fig. 5. Allelopathic effect of Prymnesium parvum cell-free filtrate on each plankton group in Expts 1 to 3 recorded on last day of the tests. $\mathrm{n}=3$, mean $\pm \mathrm{SD}$

Dinobryon sp. and the diatom Fragilaria sp. died in both the control and Prymnesium parvum filtrate treatments, so no allelopathic effect could be determined for these species and they were disregarded in the estimation of the allelopathic effect of $P$. parvum at the group level.

Microscopic observations showed that allelopathic compounds produced by Prymnesium parvum caused discolouration of other phytoplankton cells; blisters on (e.g.) dinoflagellates, nanoflagellates and diatoms; and ghost cells in cyanobacteria filaments, resulting in cell death.

\section{Effects on bacterial community}

Bacterial production in the treatments with Prymnesium parvum cell-free filtrate was lower $(3.36 \times$ $10^{-9} \mu \mathrm{g} \mathrm{C}$ bacteria $^{-1} \mathrm{~h}^{-1}$ ) than in the controls $\left(8.18 \times 10^{-9} \mu \mathrm{g} \mathrm{C}\right.$ bacteria $\left.^{-1} \mathrm{~h}^{-1}\right)$ after 4 additions of $P$. parvum filtrate and control medium, respectively (Student's $t$-test, $\mathrm{p}<$ 0.01) (Fig. 6A). However, bacteria abundance was significantly higher in the treatments that received $P$. parvum filtrate than in the controls, after Day 5 (Student's $t$-test, $\mathrm{p}<0.01$ ) (Fig. 6B).

\section{Effects on ciliates}

Ciliates were negatively affected by Prymnesium parvum cell-free filtrate. In Expt 1, ciliate numbers decreased by $90 \%$ compared to controls after 1 addition of fil- trate, and no ciliates were found after 4 additions (Fig. 7). Likewise, in Expt 2, no ciliates remained at the end of the experiment. Microscopic observation also showed blisters on ciliates $>50 \mu \mathrm{m}$ exposed to $P$. parvum filtrate before they died, while smaller ciliates $(<50 \mu \mathrm{m})$ were undetectable.

\section{DISCUSSION}

Cell-free filtrate from Prymnesium parvum culture contained compounds that negatively affected bacteria, phytoplankton (allelopathy) and ciliates from a Baltic Sea plankton community. Blooms of $P$. parvum usually attain concentrations of 50 to $100 \times 10^{6}{\text { cells } 1^{-1}}^{-1}$ (Edvardsen \& Paasche 1998, Lindholm 1998), and even as high as $10^{9}$ cells $1^{-1}$ (Edvardsen \& Paasche 1998). During our experiments we added filtrate correspond-

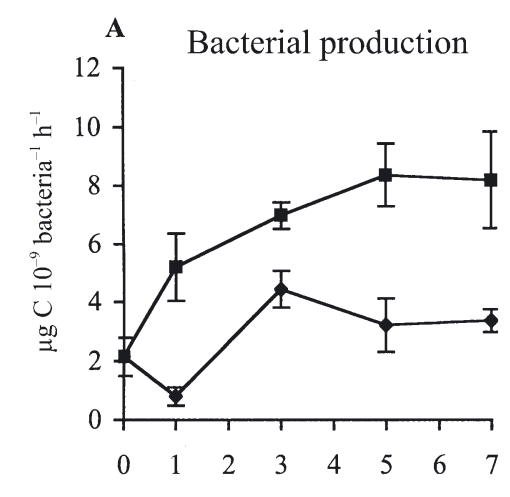

Days

Fig. 6. Bacterial production and density during Expt 1 in controls and in treatments with Prymnesium parvum cell-free filtrate. $\mathrm{n}=3$, mean $\pm \mathrm{SD}$ 


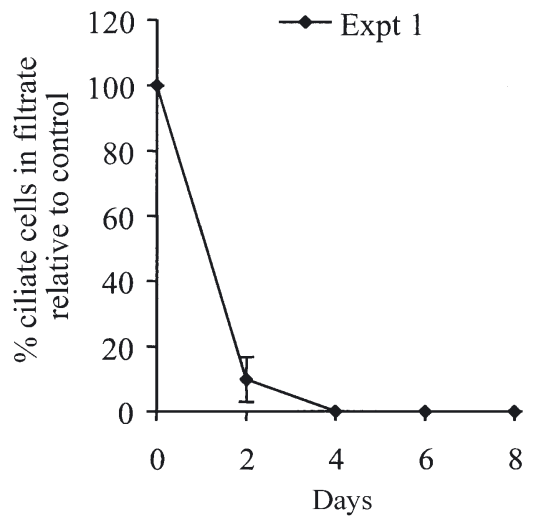

Fig. 7. Decrease in ciliate concentration during Expt 1. $\mathrm{n}=3$, mean $\pm \mathrm{SD}$

ing to $1.35 \times 10^{8}$ cells $1^{-1}$, representing a normal bloom event of $P$. parvum.

The haemolytic activity in the cell-free filtrate from Prymnesium parvum confirmed that the toxic compounds are released into the medium. Exposure of the filtrate to in vitro conditions resulted in a decrease in toxicity, indicating that the haemolytic compounds in the cell-free filtrate from $P$. parvum are degraded after release into the medium. Previous tests in our laboratory had shown that the allelopathic effect also weakens 2 to $3 \mathrm{~d}$ after exposure, and this was one reason why new additions of filtrate were made every second day in the present study. It suggests that the allelopathic effect may be related to haemolytic compounds. It has been demonstrated that the toxins produced by $P$. parvum can be inactivated by light and are sensitive to temperature (Reich \& Parnas 1962, Kvernstuen 1993 cited in Larsen \& Bryan 1998). Other algal toxins, e.g. nodularin, were also found to be sensitive to light as result of photodynamic and/or photooxidative processes by Twist \& Codd (1997), who also proposed that nodularin-metabolizing/degrading enzymes contained in cell-free extracts of Nodularia spumigena could be responsible for toxin loss. Any of these processes (or a combination of them) could be responsible for the decrease in the haemolytic activity of the P. parvum filtrate.

The general effect of Prymnesium parvum filtrate on cells which lysed upon exposure to the toxin is in accordance with the cytotoxic and haemolytic effects of $P$. parvum toxins described by Shilo (1981) and Igarashi et al. (1998), and suggests that the allelopathic effect is due to the same compounds that produce haemolysis. According to these authors, interactions of the toxin with the cell membrane are responsible for such effects, which arise from ion $\left(\mathrm{Na}^{+}\right.$and $\left.\mathrm{K}^{+}\right)$influx or from interactions of the toxins with cellular lipids; aggregation of the toxin molecules may also be involved. Also, since more than 1 toxin that provokes haemolysis and cytolysis was identified (Igarashi et al. 1995), the differential effects on planktonic organisms may indicate interaction of more than 1 compound.

The allelopathic effect of Prymnesium parvum on the whole phytoplankton community was reflected in a decrease in chlorophyll a concentration and carbon uptake, which either resulted in cell death by lysis or, at the physiological level, in a decrease in carbon uptake, whereby the cells did not die but were negatively affected (lower growth rate and carbon uptake).

The allelopathic effect of Prymnesium parvum ranged from complete suppression of growth and elimination of all cells initially present (e.g. diatoms) to partial inhibition of the growth (e.g. dinoflagellates and cyanobacteria). Since these compounds completely eliminate some of the competing phytoplankton groups and keep the biomass of others at low levels, it provides a competitive advantage to $P$. parvum, which thus has fewer species with which to compete, while those species remaining are in poor physiological condition.

One or 2 additions of Prymnesium parvum filtrate sufficed to cause a difference in chlorophyll a concentrations between control and filtrate treatments, stressing the high toxicity of the $P$. parvum allelopathic compound. Although addition of 1 or more doses of $P$. parvum filtrate cannot reproduce the continuous release of allelochemicals by the cells during a bloom event, our results suggest that phytoplankton cells exposed to $P$. parvum during a bloom event would also be negatively affected. It is interesting that in Expt 3 (20 to $150 \mu \mathrm{m}$ size fraction), which contained the most resistant phytoplankton groups, 2 additions of $P$. parvum filtrate were necessary to induce a significant difference in chlorophyll a concentrations between the filtrate treatment and the controls, while in Expts 1 and 2 only 1 addition was necessary. This confirms that dinoflagellates and cyanobacteria were the most resistant groups, and that a single exposure to the allelopathic compound may not be sufficient to have a severe effect; however, as more additions of filtrate were made, the effects became evident.

Nanoflagellates were strongly affected by Prymnesium parvum filtrate, which produced a large decrease $(97.7 \%)$ in cell numbers compared to the controls. However, their cell density at the end of the experiment (Expt 1: 233 cells $10^{3} 1^{-1}$ ) was similar to that at the beginning (175 cells $10^{3} \mathrm{l}^{-1}$ ). Our cell counts were not at the species level for the flagellates; however, Prymnesiophyceae were present in the plankton community at the end of the experiment. Since $P$. parvum does not exhibit autotoxicity (we have grown cultures up to $8 \times$ $10^{8}$ cells $^{-1}$ ) nor toxicity to other Prymnesium strains (Johansson 2000), the presence of nanoflagellates at the end of the experiment indicates that $P$. parvum allelochemicals do not harm related species. 
Prymnesium parvum usually occurs in Scandinavian waters after the diatom spring bloom and before the cyanobacteria bloom (Edler 1979, Johnsen et al. 1997). This successional pattern shows the ecological relevance of $P$. parvum filtrate, which has a higher effect on the preceeding group (diatoms), strongly inhibiting their growth, than on the succeeding group (cyanobacteria)

The lower bacterial production in the treatments with Prymnesium parvum cell-free filtrate indicated a negative effect of the released compounds by $P$. parvum on the bacterial community. The lower bacteria cell numbers in the controls, despite their higher production level, may be the outcome of a balance between bacterial growth and loss factors. Since the number of nanoflagellates in the control bottles was very high, there may have been extensive bacterial loss in this treatment due to grazing by heterotrophic/mixotrophic flagellates. Similar extensive grazing did not occur in the filtrate treatment due to the lower number of nanoflagellates in this treatment. Increased bacterial production with no concomitant increase in bacterial abundance, as found in the control treatment, has been reported previously (Shiah \& Ducklow 1994, Carlsson \& Caron 2001), and has been suggested to be the result of a balance between growth and grazing by bacterivorous organisms. In our study, the lysis of algal cells in the filtrate treatment probably increased the concentration of organic compounds. Bacteria may benefit from these compounds, and increase in density. It could be speculated that the availability of additional organic matter was responsible for the higher bacterial density in the filtrate treatments, but this is not sustained by the lower bacterial production in the filtrate treatment.

Bacteria play a fundamental role in important processes in aquatic ecosystems such as carbon flux (e.g. the microbial loop) and nutrient regeneration (Azam et al. 1983, Doucette et al. 1998). Bacteria and phytoplankton interact in the natural environment, with the bacteria being able to stimulate or inhibit phytoplankton population growth through different mechanisms such as nutrient regeneration, endosymbiosis and production of stimulatory or inhibitory compounds (Cole 1982). Therefore, the release of compounds that affect bacterial production will interfere with the whole aquatic food web.

The deleterious effect of Prymnesium parvum cellfree filtrate on ciliates demonstrated that compounds released by this species can also function as a defence strategy by eliminating potential grazers. Previous reports have shown acute effects of toxic phytoplankton species on protist grazers. The tintinnid Favella ehrenberghii showed reversal of ciliary movement leading to backward-swimming and swelling that eventually led to cell death after exposure to extracellular toxins from Alexandrium tamarense (Hansen 1989). Survival of protist grazers decreased when fed with the ichthyotoxic Chrysochromulina polylepis (Tobiesen 1991). In the environment, toxic compounds can be avoided by swimming organisms. They function as a defence mechanism that does not cause the death of the predator, but acts as a signal, triggering an avoidance reaction. Some studies have provided examples of a negative correlation between the occurrence of toxic or unpalatable phytoplankton species and copepods (Holligan et al. 1984) and ciliates (Nielsen et al. 1990). Grazers can be an important loss factor to phytoplankton biomass, and their effect on toxic phytoplankton blooms is well-documented, as in the case of a harmful algal bloom in Narragansett Bay, which was triggered by a breakdown in grazing and declined due to a subsequent increase in heterotrophic dinoflagellates (Caron et al. 1989).

Allelopathic properties have been reported for many phytoplankton species (e.g. Phaeodactylum tricornutum, Fischerella muscicola, Thrichormus doliolum, Alexandrium spp.: Sharp et al. 1979, Gross et al. 1991, von Elert \& Jüttner 1997, Arzul et al. 1999), but few studies (e.g. Pratt 1966, Keating 1977) have shown that allelopathic compounds are used by some toxic phytoplankton species to achieve dominance in the environment. Although the experiments in our study were made in the laboratory, they provide evidence that the compounds produced by toxic Prymnesium parvum can influence a natural community.

There are several studies in the literature concerning competition between phytoplankton organisms, especially competition for nutrients (e.g. Smith \& Kalff 1983, Sakshaug \& Olsen 1986, Sommer 1996). However, the role of allelopathic compounds in such interactions is just beginning to be understood. More knowledge is required regarding competition between algal species and the importance of allelopathy in such interactions. Our results showed that Prymnesium parvum release a compound that can alter the phytoplankton structure by interfering in different trophic levels, decreasing the growth and the production of phytoplankton species. Production of molecules with multiple functions (allelopathy, defence) is an efficient competitive strategy (Wolfe 2000). The production of compounds that eliminate competitors and potential grazers is an important characteristic of $P$. parvum ecology, and may be a key factor in the development of blooms in this species.

In conclusion, Prymnesium parvum releases compounds that are haemolytic, toxic to ciliates and allelopathic to bacteria and phytoplankton. The allelopathic compounds negatively affect the phytoplankton species/groups in a natural community by reducing their 
growth and production, and therefore may constitute a mechanism to outcompete other phytoplankton. These compounds also affects some phytoplankton groups more than others, thereby altering the community structure. Since the allelopathic compound released by $P$. parvum had a generalized deleterious effect on the plankton community, we suggest that the ecological significance of the allelopathic compounds released by some algal species have more implications in structuring plankton communities than previously thought.

Acknowledgements. G.O.F. thanks the Brazilian National Research Council (CNPq) for her PhD grant (process 200384/00-7). Financial support was provided by the European Commission through the BIOHAB project 'Biological control of Harmful Algal Blooms in European coastal waters: role of eutrophication' (contract EVK3-CT99-00015) as part of the EC-EUROHAB cluster, and the Swedish Research Council for Environment, Agricultural Sciences and Spatial Planning (FORMAS) (contract no. V.130-00 to E.G.). We thank C. Esplund-Lindquist, G. Wannhoff and I. Kanoshina for help with analyses of nutrients, bacterial production and carbon uptake, and also P. Carlsson for discussions about bacteria.

\section{LITERATURE CITED}

Ertebjerg-Nielsen G, Bresta AM (1984) Guidelines for the measurements of phytoplankton primary production. The Baltic Marine Biologists (BMB) Publications, Publ 1, 2nd edn. Marine Pollution Laboratory, Charlottenlund

Arzul G, Seguel M, Guzman L, Denn EE (1999) Comparison of allelopathic properties in 3 toxic Alexandrium species. J Exp Mar Biol Ecol 232:285-295

Azam F, Fenchel T, Field JG, Gray JS, Meyer-Reil LA, Thingstad F (1983) The ecological role of water-column microbes in the sea. Mar Ecol Prog Ser 10:257-263

Carlsson P, Caron DA (2001) Seasonal variation of phosphorus limitation of bacterial growth in a small lake. Limnol Oceanogr 46:108-120

Caron DA, Lim EL, Kunze H, Cosper EM, Anderson DM (1989) Trophic interactions between nano-microzooplankton and the 'brown tide'. In: Cosper EM, Bricelj VM, Carpenter EJ (eds) Novel phytoplankton blooms: causes and impacts of recurrent brown tides and other unusual blooms. Springer-Verlag, Berlin, p 265-294

Cole JJ (1982) Interactions between bacteria and algae in aquatic ecosystems. Annu Rev Ecol Syst 13:291-314

del Giorgio PA, Bird DF, Prairie YT, Planas D (1996) Flow cytometric determination of bacterial abundance in lake plankton with the green nucleic acid stain SYTO 13. Limnol Oceanogr 41:783-789

Doucette G J, Kodama M, Franca S, Gallacher S (1998) Bacterial interactions with harmful algal bloom species: bloom ecology, toxigenesis, and cytology. In: Anderson DM, Cembella AD, Hallegraeff GM (eds) Physiological ecology of Harmful Algal Blooms. NATO ASI Ser Ser G 41:619-647

Edler L (1979) Phytoplankton succession in the Baltic Sea. Acta Bot Fenn 110:75-78

Edler L, Hällfors G, Niemi Å (1984) A preliminary check-list of the phytoplankton of the Baltic Sea. Acta Bot Fennica 128:1-26
Edvardsen B, Paasche E (1998) Bloom dynamics and physiology of Prymnesium and Chrysochromulina. In: Anderson DM, Cembella AD, Hallegraeff GM (eds) Physiological ecology of harmful algal blooms. NATO ASI Ser Ser G 41:193-208

Gross EM, Wolk CP, Jüttner F (1991) Fischerellin, a new allelochemical from the freshwater cyanobacterium Fischerella muscicola. J Phycol 27:686-692

Guillard RR (1975) Culture of phytoplankton for feeding marine invertebrates. In: Smith WL, Chanley MH (eds) Culture of marine invertebrate animals. Plenum Press, New York, p 29-60

Hansen PJ (1989) The red tide dinoflagellate Alexandrium tamarense: effect on behaviour and growth of a tintinnid ciliate. Mar Ecol Prog Ser 53:105-116

Holligan PM, Harris RP, Newell RC, Harbour DS and 5 others (1984) Vertical distributions and partitioning of organic carbon in mixed, frontal and stratified waters of the English Channel. Mar Ecol Prog Ser 14:111-127

Holmquist E, Willém T (1993) Fish mortality caused by Prymnesium parvum. Vatten 49:110-115

Igarashi T, Oshima Y, Murata M, Yasumoto T (1995) Chemical studies on prymnesins isolated from Prymnesium parvum. In: Lassus P, Arzul G, Erard E, Gentien P, Marcaillou C (eds) Harmful marine algal blooms. Lavoisier Intercept, New York, p 303-308

Igarashi T, Satake M, Yasumoto T (1996) Prymnesin-2: a potent ichthyotoxic and hemolytic glycoside isolated from the red tide alga Prymnesium parvum. J Am Chem Soc 118:479-480

Igarashi T, Aritake S, Yasumoto T (1998) Biological activities of Prymnesin-2 isolated from a red tide alga Prymnesium parvum. Nat Toxins 6:35-41

Jespersen AM, Christoffersen K (1987) Measurements of chlorophyll a from phytoplankton using ethanol as extraction solvent. Arch Hydrobiol 109:445-454

Johansson N (2000) Ecological implications of the production of toxic substances by fish killing phytoplankton species grown under variable N:P-ratios. PhD thesis, Department of Ecology, Lund University

Johnsen G, Volent Z, Tangen K, Sakshaug E (1997) Time series of harmful and benign phytoplankton blooms in the northwest European waters using the seawatch buoy system. In: Kahru M, Brown CW (eds) Monitoring algal blooms: new techniques for detecting large-scales environmental change. Landes Bioscience, Austin, TX, p 113-139

Keating KI (1977) Allelopathic influence on blue-green bloom sequence in a eutrophic lake. Science 196:885-886

Larsen A, Bryant S (1998) Growth and toxicity in Prymnesium parvum and Prymnesium patelliferum (Haptophyta) in response to changes in salinity, light and temperature. Sarsia 83:409-418

Larsen A, Eikrem W, Paasche E (1993) Growth and toxicity in Prymnesium patelliferum (Prymnesiophyceae) isolated from Norwegian waters. Can J Bot 71:1357-1362

Legrand C, Rengefors K, Granéli E, Fistarol GO (in press) Allelopathy in phytoplankton-biochemical, ecological and evolutionary aspects. Phycologia

Lindholm T (1998) Algfenomen och algproblem. Åbo Akademi, Åbo

Nielsen TG, Kiørboe T, Bjørnsen PK (1990) Effects of a Chrysochromulina polylepis subsurface bloom on the planktonic community. Mar Ecol Prog Ser 62:21-35

Pratt DM (1966) Competition between Skeletonema costatum and Olithodiscus luteus in Narragansett Bay and in culture. Limnol Oceanogr 11:447-455

Reich K, Parnas I (1962) Effect of illumination on ichthyotoxin 
in axenic culture of Prymnesium parvum Carter. J Protozool 9:38-40

Sakshaug E, Olsen Y (1986) Nutrient status of phytoplankton blooms in Norwegian waters and algal strategies for nutrient competition. Can J Fish Aquat Sci 43:389-396

Sharp JH, Underhill PA, Hughes DJ (1979) Interaction (allelopathy) between marine diatoms: Thalassiosira pseudonana and Phaeodactylum tricornutum. J Phycol 15:353-362

Shiah F, Ducklow HW (1994) Temperature and substrate regulation of bacterial abundance, production and specific growth rate in Chesapeake Bay, USA. Mar Ecol Prog Ser 103:297-308

Shilo M (1981) The toxic principles of Prymnesium parvum. In: Carmichael WW (ed) The water environment: algal toxins and health. Plenum Press, New York, p 37-47

Simon M, Azam F (1989) Protein content and protein synthesis rates of planktonic marine bacteria. Mar Ecol Prog Ser 51:201-213

Smith DC, Azam F (1992) A simple, economical method for measuring bacterial protein synthesis in sea water using ${ }^{3}$ H-leucine. Mar Microb Food Webs 6:107-109

Smith REH, Kalff J (1983) Competition for phosphorus among co-occurring freshwater phytoplankton. Limnol Oceanogr 28:448-464

Sommer U (1996) Nutrient competition experiments with periphyton from the Baltic Sea. Mar Ecol Prog Ser 140:161-167

Editorial responsibility: Otto Kinne (Editor),

Oldendorf/Luhe, Germany
Stolte W, Panosso R, Gisselson LÅ, Granéli E (2002) Utilization efficiency of nitrogen associated with riverine dissolved organic carbon ( $>1 \mathrm{kDa}$ ) by two toxin-producing phytoplankton species. Aquat Microb Ecol 29:97-105

Tobiesen A (1991) Growth rates of Heterophrys marina (Heliozoa) on Chrysochromulina polylepis (Prymnesiophyceae). Ophelia 33:205-212

Twist H, Codd GA (1997) Degradation of the cyanobacterial hepatotoxin, nodularin, under light and dark conditions. FEMS Microbiol Lett 151:83-88

Utermöhl H (1958) Zur Vervollkommnung der quantitativen Phytoplankton Methodik. Mitt Int Ver Theor Angew Limnol 9:1-38

Valderama JC (1995) Methods of nutrient analysis. In: Hallegraeff GM, Anderson DM, Cembella AD (eds) Manual of harmful marine microalgae. IOC and guides, no. 33. UNESCO, Paris, p 251-268

Valiela I (1995) Marine ecological processes, 2nd edn. Springer-Verlag, Berlin

von Elert E, Jüttner F (1997) Phosphorus limitation and not light controls the extracellular release of allelopathic compounds by Trichormus doliolum (Cyanobacteria). Limnol Oceanogr 42:1796-1802

Wolfe GV (2000) The chemical defence ecology of marine unicellular plankton: constraints, mechanisms, and impacts. Biol Bull 198:225-244

Submitted: November 11, 2002; Accepted: February 18, 2003 Proofs received from author(s): June 4, 2003 